FIU Law Review

Spring 2010

\title{
Defending the NLRB: Improving the Agency's Success in the Federal Courts of Appeals
}

Jeffrey M. Hirsch

University of Tennessee College of Law

Follow this and additional works at: https://ecollections.law.fiu.edu/lawreview

Part of the Other Law Commons

Online ISSN: 2643-7759

\section{Recommended Citation}

Jeffrey M. Hirsch, Defending the NLRB: Improving the Agency's Success in the Federal Courts of Appeals, 5 FIU L. Rev. 437 (2010).

DOI: https://dx.doi.org/10.25148/lawrev.5.2.11

This Article is brought to you for free and open access by eCollections. It has been accepted for inclusion in FIU Law Review by an authorized editor of eCollections. For more information, please contact lisdavis@fiu.edu. 


\title{
Defending the NLRB: Improving the Agency's Success in the Federal Courts of Appeals
}

\author{
Jeffrey M. Hirsch ${ }^{*}$
}

Commentators have made innumerable recommendations to improve the National Labor Relations Board's (NLRB or Board) administration of the National Labor Relations Act (NLRA). ${ }^{1}$ Yet one subject that has been largely ignored in these discussions is the fact that no matter how good the administrative enforcement of the NLRA is, or could be, it will mean very little if the NLRB cannot defend its decisions in the courts of appeals. ${ }^{2}$

Virtually all measures that would improve the NLRB's overall administrative effectiveness would also have a positive impact on the agency's success in the courts of appeals. However, the focus of this article is more narrow, as it addresses reforms intended to directly improve the willingness of courts of appeals to enforce NLRB decisions.

Although the NLRB suffers at times from a reputation as an inept agency, that reputation is often unjustified, particularly with regard to the success rate of its decisions before the federal courts of appeals. For instance, in Fiscal Year 2009, the Board had sixty-one cases decided by appellate courts. $^{3}$ Out of those cases, approximately $78.7 \%$ were enforced in full, $4.9 \%$ enforced with modifications, $6.6 \%$ remanded in full, $4.9 \%$ partially affirmed and partially remanded, and $4.9 \%$ set aside in full. ${ }^{4}$ This

* Jeffrey M. Hirsch is Associate Professor at University of Tennessee College of Law and Visiting Associate Professor at Vanderbilt University Law School. Professor Hirsch is indebted to Fred Jacob, Meredith Jason, Anne Marie Lofaso, Kira Vol, Dennis Walsh, Peter Winkler, and participants at Florida International University College of Law's Whither the Board?: The National Labor Relations Board at 75 Symposium for their extremely helpful input. Professor Hirsch also thanks Justin Faith, Tamra Jordan and Laura Robinson for their research assistance. Much of the insights of this article are the result of Professor Hirsch's prior experience as an attorney in the NLRB's Appellate Court Branch from 2000 to 2004.

1 See, e.g., Samuel Estreicher, Improving the Administration of the National Labor Relations Act without Statutory Change, 25 ABA J. LAB. \& EMP. L. 1 (2009) [hereinafter Improving].

2 Some exceptions include James J. Brudney, A Famous Victory: Collective Bargaining Protections and the Statutory Aging Process, 74 N.C. L. REV. 939, 973 (1996), and Joan Flynn, The Costs and Benefits of "Hiding the Ball": NLRB Policymaking and the Failure of Judicial Review, 75 B.U. L. REV. 387, 442-43 (1995).

374 NLRB ANNUAL REPORT: FisCAL YEAR 2009, at 147 (2009).

4 Id. at $147-48$. 
success is typical of other years and shows that courts are far more likely to approve of the NLRB's decisions than disapprove. ${ }^{5}$ Moreover, this win rate is roughly in line - albeit a bit lower - with other labor and employment agencies that engage in significant levels of adjudication. ${ }^{6}$ Thus, it does not appear that the Board is performing substantially worse than other agencies. That does not mean, however, that it cannot still perform better than it does now.

Indeed, although the NLRB's overall rate of success is not problematic, much of that success is due to the large percentage of straightforward cases that the Board hears. Of more concern are the more contentious cases - ones that involve highly contested facts or controversial rules. There is little empirical evidence that looks specifically to the Board's success in those cases, but the evidence that does exist suggests that the Board is not receiving the deference that one might expect for an administrative agency. ${ }^{7}$ Judges often seem not to respect the Board or, at a minimum, have no hesitation reversing a decision with which they have the slightest disagreement. Ways in which the Board might be able to reverse this trend is the focus of this article.

The stakes of this inquiry are high. Because the NLRB cannot enforce its own orders, any losing party can delay compliance with a Board order by seeking review before an appellate court. ${ }^{8}$ This delay itself can substan-

5 The Fiscal Year 2009 success rate is an improvement over the Board's overall averages (from July 5, 1936 to September 30, 2009), in which it had 12,107 cases decided by the federal courts of appeals, and approximately $66.5 \%$ were enforced in full, $12.9 \%$ enforced with modifications, $5.0 \%$ remanded, $2.3 \%$ partially affirmed and partially remanded, and $13.3 \%$ set aside. Id. at 147 . However, it is in line with the Board's average over the previous five fiscal years, in which it had 279 cases decided by the federal courts of appeals, and approximately $78.8 \%$ were enforced in full, $6.5 \%$ enforced with modifications, $4.8 \%$ remanded, $3.1 \%$ partially affirmed and partially remanded, and $6.8 \%$ set aside. Id. at 148 .

6 For instance, over the period covering Fiscal Years 2004-2009, the NLRB had $78.80 \%$ of its cases affirmed in full by appellate courts. 74 NLRB ANNUAL REPORT: FISCAL YEAR 2009, at 148 (2009). Other agencies' win rates - as determined by searches on Westlaw - over that same period of time include: the Federal Labor Relations Authority (56.4\%); the Department of Labor's Benefit Review Board (83.27\%); the Department of Labor's Administrative Review Board (91.2\%); and the Merit Systems Protection Board (85.56\%). These comparisons are limited in what they can show given differences in the number and type of cases, but they illustrate that the NLRB is not an outlier among adjudicatory labor and employment agencies.

7 James Brudney has studied all circuit court review of NLRB decisions over an earlier time frame and noted areas in which the courts - especially the D.C. Circuit - are particularly likely to reverse the Board, such as cases involving affirmative bargaining orders. See Brudney, supra note 2, at 1012.

8 However, most NLRB decisions are not appealed. For instance, a rough approximation of the appeals rate in Fiscal Year 2008 is $31 \%$, which is based on 330 contested cases decided by the NLRB over that time period, with 103 cases assigned to the Appellate Court Branch over the same period (sixty-three of those from appeals by the losing party; forty referred by the NLRB Regional Office because the losing party failed to comply with the NLRB order). 73 NLRB ANNUAL REPORT: FISCAL 
tially undermine employees' labor rights - particularly when a case involves representational issues, in which employees' support for a union often diminishes as time passes. ${ }^{9}$ Yet the problems associated with delay are exacerbated if losing parties believe they have a good chance of winning before the courts. Although some parties may challenge a Board order no matter their chances, others may seriously weigh the costs and benefits of further litigation. For these parties, the prospect of reversing a Board order may lead to additional challenges, more delay, and ultimately an inability of employees to enjoy their labor rights.

Many factors contribute to the Board success vel non in the appellate courts. However, it must be acknowledged that one of the most significant factors is out of the Board's control. Although there are disagreements about the extent to which judges' beliefs influence their decisionmaking, ${ }^{10}$ there is little doubt that the judiciary's views on labor law influence the outcome of NLRB cases. ${ }^{11}$ The impact of judges' beliefs can be overstated, but the NLRB has little room to maneuver if it tries to defend a close case before judges who appear to disagree fundamentally with the purpose of the NLRA. ${ }^{12}$ This article will note some reforms that may convince even these judges to side with the Board more than they do now, but the primary focus will be on reforms over which the Board has more control.

These reforms include attempting to improve the format and substance of NLRB decisions, increasing the emphasis on the standard of review, considering limited types of forum shopping, increasing the use of rulemaking, reducing delay, and requesting more injunctive relief. None of these strategies, if enacted, would be a silver bullet that would solve all of the difficul-

YEAR 2008, at 14 (2009); NLRB General Counsel Issues Report On 2008 Operations 7, available at http://www.nlrb.gov/shared_files/Press\%20Releases/2008/R-2675.pdf.

$9 \quad$ See James Brudney, Neutrality Agreements and Card Check Recognition: Prospects for Changing Paradigms, 90 IowA L. REV. 819, 832 (2005); Michael Harper, The Case for Limiting Judicial Review of Labor Board Certification Decisions, 55 GEO. WASH. L. REV. 262, 264-65 (1987); see also Kate Bronfenbrenner, Employer Behavior in Certification Elections and First-Contract Campaigns: Implications for Labor Law Reform, in RESTORING THE PROMISE OF AMERICAN LABOR LAW 75, 78-79 (Sheldon Friedman et al. eds., 1994) (describing win rate declining from 50\% if election occurs within 50 days after election petition, to $31 \%$ if election occurs 61-180 days later), available at http://digitalcommons.ilr.cornell.edu/articles/18/.

10 Compare Richard L. Revesz, Ideology, Collegiality, and the D.C. Circuit: A Reply to Chief Judge Harry T. Edwards, 85 VA. L. REV. 805, 851 (1999), with Harry T. Edwards, Collegiality and Decision Making on the D.C. Circuit, 84 VA. L. REV. 1335, 1335 (1998).

11 See Brudney, supra note 2, at 1019-20 (describing courts' willingness to reverse the Board in certain areas as primarily the result of differing views on what the NLRA should mean, particularly courts' emphasis on employee free choice).

12 This is not to say that such judges eschew their responsibility to apply the law; indeed, the NLRB's overall success rate indicates that this happens often. However, it is the controversial or close cases in which a judge's predilection against unionism appears to raise its head most often. 
ties that the Board faces in court. In the aggregate, however, they could improve the Board's standing in the eyes of federal appellate courts, thereby improving the Board's long-term success. Moreover, a renewed focus on the need to win before the courts of appeals could enhance the Board's success in the short term by improving some of its individual decisions, thereby making them better candidates for court enforcement.

\section{REFORMING NLRB DECISIONS}

Among the possible means to improve the NLRB's appellate success, perhaps none holds as much promise and covers as many issues as reforming the Board's actual decisions. This is perhaps no surprise, as the decisions themselves are what the courts are being asked to accept or reject. Unfortunately, the NLRB writes its decisions not with the courts in mind, but rather NLRB insiders or experts. And not merely any labor law junkie; rather, NLRB decisions appear most targeted to the readers who existed in the 1930s, for its decisions look virtually the same today as they did then. Accordingly, updating the form and substance of Board decisions could improve their quality, making them more accessible to judicial readers and more defensible in court.

In addition to some of the specific recommendations that follow, one general practice that would likely make NLRB decisions more palatable to courts would be to give Board-side attorneys appellate court experience. The Board could focus on hiring attorneys with appellate experience whether with the NLRB or not - or by giving Board-side attorneys temporary "details" to the NLRB's Appellate Court Branch. Nothing would cement the need to write easy-to-understand and well-reasoned decisions like the experience of having to defend a confusing and poorly reasoned one before often hostile judges.

\section{A. Updating Format of NLRB Decisions}

To observe the problems with NLRB decisions one need go no farther than looking at them, as the format of today's NLRB decisions are virtually identical to decisions from $1937 .^{13}$ This is not a good thing. Even if the

13 To be fair, the NLRB's decisions have been updated a bit over the last decade or so. However, that improvement still has a long way to go. See, e.g., Guard Publ'g Co. (The Register-Guard), 351 N.L.R.B. 1110 (2007) (providing useful introductory summary of decision), enforced in part, enforcement denied in part, 571 F.3d 53 (D.C. Cir. 2009). Indeed, the format of the very first published decision of the NLRB still looks remarkably similar to very recent NLRB decisions. Compare Pa. Greyhound Lines, Inc., 1 N.L.R.B. 1 (1935), with ABC Indus. Laundry, LLC, Nos. 28-CA-22133, 28CA-22219 \& 28-CA-22286, 355 N.L.R.B. No. 17, 2010 WL 991195 (Mar. 2, 2010) (summary adoption of ALJ decision, which uses the 1935 format). 
1930s format and structure made sense at one time, it looks foreign to the modern reader. Although cosmetic, this antiquated format makes NLRB decisions harder to read and understand, which undermines the Board's ability to communicate to the courts the reasons for its findings. Most judges do not see enough NLRB decisions to feel comfortable with this format; the problem is even worse for their less experienced law clerks, who are likely to view NLRB decisions as something bordering on a foreign language. ${ }^{14}$ Further, many judges are already perceived as being hostile to labor rights, or at least unfamiliar with the realities that many employees face, which makes it especially important that the Board present its holdings in as clear a manner as possible. ${ }^{15}$

The problems with the format of NLRB decisions begin right from the start. Rather than simply describing the basic issues involved in the case, an NLRB decision often leads off with administrative boilerplate. ${ }^{16}$ It may then describe or summarily affirm an attached administrative law judge (ALJ) recommended decision, while noting - almost always in a footnote certain challenges to the ALJ decision that the Board is rejecting. Take this example of an introduction from one of the Board's recent cases:

On September 28, 2009, Administrative Law Judge Burton Litvack issued the attached decision. The Respondent filed exceptions and a supporting brief, the General Counsel filed an answering brief, and the Respondent filed a reply brief.

The National Labor Relations Board has considered the judge's decision and the record in light of the exceptions and briefs, and has decided to affirm the judge's rulings, findings, and conclusions and to adopt the Recommended Order as modified. ${ }^{17}$

This example is typical of many NLRB introductions, which is unfortunate because it tells the reader nothing substantive about the case. ${ }^{18}$ Indeed, to a reader unaccustomed to Board procedure, this introduction is so full of terms of art and other jargon that it borders on meaningless.

\footnotetext{
14 Indeed, my personal conversations with various law clerks about their first experience with NLRB decisions usually elicit descriptions such as "goofy" or "bizarre."

15 See James J. Brudney, Isolated and Politicized: The NLRB's Uncertain Future, 26 COMP. LAB. L. \& POL'Y J. 221, 239 (2005); Flynn, supra note 2, at 442-43.

16 See, e.g., ABC Indus. Laundry, LLC, 355 N.L.R.B. No. 17, at*1.

17 Id. (internal citations omitted).

18 Other introductions will often at least mention the statutory provision allegedly violated and perhaps some fact, but the rest of the format is often similar, and the useful information is often buried along with a detailed description of the procedural posture. See, e.g., DPI New England, No. 1-CA44833, 354 N.L.R.B. No. 94, 2009 WL 3577752, at*1, 2 (Oct. 30, 2009). The ALJ's decisions in these cases are generally no better. See, e.g., ABC Indus. Laundry, LLC, 355 N.L.R.B. No. 17, at*2.
} 
A particular problem in this example is that the two sentences quoted above are literally the entire Board decision, accompanied only by an order and the adopted ALJ decision. Although this type of "short form" adoption of an ALJ decision may be appropriate at times, its format leaves much to be desired. This is especially true given that the ALJ decisions are often more confusing than the Board's. ${ }^{19}$ What is particularly unfortunate about these short form decisions is that when the Board refuses to use them, its introductions - at least recently - are markedly better, as they provide some information about the legal issue in the case and perhaps some basic facts. ${ }^{20}$

The Board should build on these more helpful introductions by ensuring that all cases begin in a way that actually introduces the reader to the case. One recent example is from an ALJ recommended decision, which starts:

In this case the Government alleges that a union has unlawfully refused an employer's demand to negotiate a successor labor agreement to replace the parties' last agreement. The predecessor agreement, not atypically, was governed by a provision that required 60days written notice to amend or terminate to avoid renewal of the agreement for one year. The issue in this case is whether the employer provided the union with such notice. If it did not, then, by its terms, the agreement renewed and - pursuant to Section $8(\mathrm{~d})$ of the National Labor Relations Act (the Act) ${ }^{1}$ - the union was not under a statutory duty to bargain for a new agreement to take effect before the extended renewal date of January 14, 2010. On the other hand, if the employer did provide sufficient notice to the union, the agreement, by its terms, terminated January 14, 2009, and the union's refusal to bargain a successor collective-bargaining agreement was, and is, as alleged, a violation of the duty to bargain, pursuant to Section 8(b)(3) of the Act. ${ }^{21}$

Unlike the previous example, this introduction is helpful to the reader, as it sets out the legal issue in question and notes the key factual inquiry, as well as the consequences of the alternative arguments regarding that inquiry. Perhaps the only significant improvement that could be made to this introduction would be to note the ALJ's conclusions about the issues involved.

\footnotetext{
19 See ABC Indus. Laundry, LLC, 355 N.L.R.B. No. 17, at *2.

20 See, e.g., McCarthy Constr. Co., Nos. 7-CA-51474 \& 7-CA-51647, 355 N.L.R.B. No. 10, 2010 WL 454506, at *1 (Feb. 2, 2010).

21 Int'1 Ass'n of Machinists and Aerospace Workers of Am., Case No. 4-CB-10259, at 1 (N.L.R.B. Div. of Judges Sept. 9, 2009) (ALJ David I. Goldman, decision and order), available at http://www.nlrb.gov/shared_files/_ALJ\%20Decisions/2009/JD-43-09.htm.
} 
Another important contrast between the two introductions is that the second example uses footnotes only to quote the cited statutory provisions. The first example, however, manages to have a total of six footnotes in a single sentence. Although some of the material in these footnotes may be deemed inappropriate for the text, ${ }^{22}$ the information in the others is far more substantive than virtually anything else in the text. For example, the fourth footnote contains four long paragraphs in which the Board discusses several challenges to the ALJ's recommendations, a brief discussion of the relevant recommendations, and the Board acceptance of some of them and refusal to rely on others. This type of information is what is supposed to constitute the decision, not some minor side issue. By placing virtually all substantive information in a footnote, the Board made its decision very difficult to read and left the reader with a poor impression of the agency's competence.

After the introduction, what might follow is a brief description of the Board's differences with the ALJ. However, this part of the decision typically assumes that the reader is aware of the ALJ's decision. ${ }^{23}$ As a result, the reader must frequently flip back and forth between the two decisions - a requirement that not only makes comprehension difficult, but makes the reader ill-disposed towards the Board from the beginning. This problem is particularly severe when the ALJ has issued a bench decision, a practice that should be completely prohibited, as it often results in extremely difficult-to-understand fact finding and analysis. ${ }^{24}$

In more significant cases, the Board may write a full decision. Although better than a full or partial adoption of the ALJ's decision, these can still be difficult to read. These decisions generally state the facts often with an extremely high degree of specificity - and then, in some cases, explain in full the positions of both parties. ${ }^{25}$ It is only then the Board itself provides its legal analysis. It is telling that it is not unusual for the background material to be longer than the Board's analysis, presumably the most important part of the decision. ${ }^{26}$ This simple numerical fact

22 For example, the Board's statement that it continues to issue two-member decisions or the fact that the parties did not object to certain findings might be worthy of a footnote. However, given that reviewing appellate courts rarely use footnotes, there is a good argument to be made that these statements should be in the text as well. See ABC Indus. Laundry, LLC, 355 N.L.R.B. No. 17, at*1 nn.1-2.

23 Id. at 1 n. 4.

24 See, e.g., Avante of Boca Raton, 334 N.L.R.B. 381, 382-90 (2001).

25 See, e.g., Guard Publ'g Co. (The Register-Guard), 351 N.L.R.B. 1110, 1111-14 (2007), enforced in part, enforcement denied in part, 571 F.3d 53 (D.C. Cir. 2009) (discussing facts, ALJ's decision, parties' arguments, and positions of amici).

26 Compare ABC Indus. Laundry, LLC, 355 N.L.R.B. No. 17, at*1-8 (providing NLRB and ALJ background), with id. at $1 \mathrm{nn} .4$ \& 8-13 (providing NLRB and ALJ legal analysis). 
diminishes the Board's analysis, because its belabored focus on the background - particularly the parties' positions - has exhausted many readers.

A far better approach would be to adopt the format of court decisions. ${ }^{27}$ One obvious advantage is that courts are used to this format and familiarity would breed comfort with the Board's conclusions. Moreover, courts typically provide only the facts needed for the reader to understand the decision - eliminating the risk of having important facts lost in a swamp of irrelevant ones or overlooked by a bored reader.

It is true that the NLRB, which is technically a fact-finding adjudicator, is in a different position than an appellate court and its decisions often need more factual development. Yet the NLRB is typically not in the same position as a district court because the Board does not conduct hearings itself - that is the function of ALJs. The closest parallel is a district court's review of a magistrate judge's recommended order. Like in the magistrate situation, the initial ALJ decision can be helpful. It is the ALJ who is really responsible for developing the evidence, acting like the magistrate judge to a district court or, where there is no magistrate, a district court to an appellate court. ALJ decisions, therefore, are expected to have a more thorough factual development. Consequently, the NLRB should use ALJ decisions like appellate courts use district court decisions or like district courts use magistrate recommendations. The Board should give its own summary of the relevant facts, knowing that more detail is available in the ALJ decision. ${ }^{28}$ Merely referring to the ALJ decision or replicating its detail, makes its decisions far less accessible.

Reciting in detail each party's arguments is also overkill. This is particularly true because NLRB decisions list those arguments by party, rather than by issue. Thus, appellate judges and clerks must read through a detailed description of each party's arguments, then once the Board finally begins its analysis of the issues, repeatedly turn back to those descriptions to find each party's approach to a given issue. ${ }^{29}$ There are better alterna-

27 For instance, the ALJ's decision in NFI Indus. Inc., No. 4-CA-36842, 2010 WL 332166 (N.L.R.B. Div. of Judges Jan. 8, 2010), although a bit long, reads a lot like a court decision, with a substantive summary introducing the case, a brief recitation of the procedural posture and jurisdiction, a discussion of the facts, and the analysis compromising the bulk of the decision. It is perhaps not coincidence that the ALJ, David Goldman, is a former appellate attorney for the Board. See, e.g., Caterpillar, Inc. v. NLRB, 138 F.3d 1105 (7th Cir. 1998).

28 The Board would obviously need more explanation if it makes a different factual finding than the ALJ.

29 It is possible that the Board is attempting to give its decisions a flavor of notice-and-comment rulemaking by making the parties' input to its ultimate decision more explicit. Yet, given that an NLRB decision will always fall far short of formal rulemaking no matter how it characterizes the parties' arguments, this strategy - if true - has far more costs than benefits. 
tives to forcing judges to endure this time-consuming and frustrating manner of reading a decision.

For instance, the Board could make parties' briefs publicly accessible and allow ALJs to continue their practice of providing detailed descriptions, while the Board merely summarizes the parties' arguments. This approach could also mirror the format of most appellate courts, which typically weave each party's arguments into the courts' analyses of a given issue. ${ }^{30}$ In addition to aiding comprehension, and indirectly enhancing respect for the Board's decision, this change could also make the Board more responsive to parties' arguments. Under its current practice, it appears that after describing the parties' arguments, the Board occasionally leaves them in their separate sections and never returns to address them.

Following its description of the parties' arguments is the Board's legal analysis. As a matter of format, there is little more that the Board should do, aside from doing more to incorporate the facts and the parties' contentions into its legal analysis. Otherwise the format of the Board's legal analysis currently resembles that of most appellate courts. However, there are more substantive issues with the Board's analysis, which are discussed below.

The last step in an NLRB decision is its order, which is one of the more effective portions of its decisions. It is here that the Board lists exactly what violations it has found and the remedies, all in a relatively easy-to-read format. Indeed, the first thing I do when reading a Board decision is to look at the order, as that tells me exactly what the Board found, some very basic facts, and how the Board remedied the violations. The problem is that the order is buried somewhere in the document, between the decisions of the Board and the ALJ. The Board instead should provide the same, basic information at the start of each case. It could do so in paragraph form, as part of the overall introduction to the case. This introduction should explicitly, and simply, state the violations found and complaints rejected. $^{31}$ Simpler cases could also note the remedies, while more complex cases could refer the reader to the specific page number where the full Board order is located.

The Board should also eliminate the adoption of ALJ decisions in all but the simplest of cases - much like appellate courts' decision to issue 2002).

30 See, e.g., Hartman Bros. Heating \& Air Conditioning Co. v. NLRB, 280 F.3d 1110 (7th Cir.

31 As noted, the Board appears to be moving more in this direction lately. See McCarthy Constr. Co., Nos. 7-CA-51474 \& 7-CA-51647, 355 N.L.R.B. No. 10, 2010 WL 454506, at *1 (Feb. 2, 2010); supra text accompanying note 20 . 
summary affirmances. $^{32}$ Moreover, partial adoption of ALJ decisions should be ended. It is a confusing practice that demands a great deal of care from the reader to determine exactly what the Board is holding, as the Board may agree with parts of the ALJ's conclusions and reasoning; reject other parts; or agree with the ALJ's conclusions, but not its reasoning. ${ }^{33}$ If the Board feels that an issue needs a different approach than the ALJ provides, it should simply provide that approach itself. ${ }^{34}$ It would not have to reinvent the wheel, as it could still summarize the ALJ decision, but the practice of having part of the Board's actual findings contained in a partially adopted ALJ decision is far too confusing.

Minor issues with NLRB decisions exist as well. For instance, the Board should significantly reduce its use of footnotes. Any factual finding or legal conclusion should be in the text of a decision, as any material in a footnote seems trivial or an afterthought. ${ }^{35}$ This is especially true when the Board disagrees with the ALJ. ${ }^{36}$ Moreover, for the sake of an increasingly large group of judges who may not have the eyesight of their youth, the Board needs to increase the font size in its decisions. ${ }^{37}$ A minor point to be sure, but the Federal Rules of Appellate Procedure require 14-point sized font in appellate briefs for a reason. ${ }^{38}$

One other possible reform is to identify the authors of NLRB decisions, as is the practice in many court decisions. Yet this reform may do more harm than good. One argument for authorship is that Board members and their staffs may take more care when writing their decisions. The danger, however, is that this care comes at the expense of speed. For most Board decisions, the costs of delay are likely to outweigh any benefit of authorship, ${ }^{39}$ although exceptions may exist for major cases. For instance,

32 See, e.g., Greene v. NLRB, 321 F. App'x 816 (11th Cir. 2009); see also ABC Indus. Laundry, LLC, Nos. 28-CA-22133, 28-CA-22219 \& 28-CA-22286, 355 N.L.R.B. No. 17, 2010 WL 991195, at *2 (Mar. 2, 2010); McCarthy Constr. Co., 355 N.L.R.B. No. 10, at*1; supra text accompanying notes 1920 .

33 See, e.g., ABC Indus. Laundry, LLC, 355 N.L.R.B. No. 17, at *1 nn.4 \& 6.

34 There may be limited instances in a case with multiple, yet straightforward, issues that the Board wants to adopt the ALJ decision except for a single (or a few) narrow issues. If this is the case, the Board should, at a minimum, make it absolutely clear exactly what it is adopting and what it is not including referring to section or page numbers in the ALJ decision.

35 There was often a joke among Board attorneys - unfortunately one more true than funny - that if you want to see what is important in an NLRB decision you must look to the footnotes.

36 See, e.g., Tower Auto. Operations USA I, Nos. 13-CA-44668 \& 13-CA-44894, 355 N.L.R.B. No. 1, 2010 WL 454497, at *1 nn.5-6, 8-9 \& 11 (Jan. 15, 2010) (overruling or refusing to adopt ALJ factual findings or credibility determinations).

37 The Board's font size is so small, even those with good eyesight will feel the strain of reading after a while.

38 FED. R. App. P. 32(a)(5).

39 See supra note 9. 
where there is a full Board decision or some other major issue at stake, identifying a decision's author may provide an added degree of care that proves to be valuable. Authorship is also unlikely to substantially affect the amount of time needed to release these cases as they are significant enough to be on their own schedule.

One final aspect to the NLRB's current decision format is that it may provide a perverse advantage. Confusion may work to the Board's benefit if courts are willing to look to the NLRB's appellate attorneys as experts in deciphering Board decisions. However, this is a remote benefit. Judges are not accustomed to relying on attorneys as experts in interpreting decisions that is the judges' job. More likely is that the judges view the NLRB's conclusions as being as archaic and confused as its decisions. A better approach, therefore, would be to write its decisions in a comprehensible manner that reflects well on the Board's competence.

\section{B. Better Explanations}

Beyond the antiquated format of its decisions, one of the biggest problems for appellate review is the Board's failure to adequately explain itself. There can be many reasons for this failure, from sloppiness to the gaps in logic that can result when insiders talk to each other, but the end result is a decision that - to an outsider at least - looks inadequately reasoned. This is by no means a universal problem, as the Board often provides good explanations. However, this problem is not a rare one either; it is not unusual to see decisions that do a cursory, or worse, job of explaining how the Board reached a certain conclusion.

This problem has not gone unnoticed by the Board. In one case, Comcast Cablevision-Taylor, ${ }^{40}$ Member Acosta wrote a concurrence decrying the Board's failure to explain its current approach to an issue with inconsistent Board precedent. ${ }^{41}$ An appellate court had reversed the Board in its original Comcast decision and the Board's handling of that remand simply followed the court decision without addressing the underlying inconsistencies. Member Acosta objected to this failure, stressing that it would lead to "confusion [that] may provide a basis for courts of appeals to deny enforcement in the future." 42

\footnotetext{
40338 N.L.R.B. 1089, 1089-90 (2003).

41 The issue involved whether a union's grant of benefits - in Cablevision, a paid trip to a meeting valued at $\$ 50$ - warranted setting aside an election. Id.

42 Id. at 1089 (citing Owens-Illinois, Inc., 271 N.L.R.B. 1235 (1984) (overturning election based on $\$ 16$ jackets)). In the Board's defense, it did not have an absolute need to clarify its position on preelection gifts in Comcast, as it was merely implementing the court's decision in the remanded case. Yet,
} 
Failures of the Board to adequately explain its reasoning, like in Comcast, is an extremely serious problem. In addition to making the Board look sloppy or disingenuous, the rules governing appellate review of administrative adjudication make incomplete reasoning a killer for NLRB decisions. For instance, the Chenery rule prevents a court from enforcing an agency order on grounds that the agency itself did not rely upon. ${ }^{43}$ The rationale for Chenery is fairness to the parties and recognition that a court cannot adequately review a decision based on reasons not contained in the decision itself. $^{44}$ As a result, the Board must always be cognizant of the fact that its appellate attorneys cannot invent arguments to defend what may well be a justified result; if an argument is not in the Board decision, it may as well not exist. Making sure that it always adequately explains all of its reasoning would avoid forcing the Board's appellate attorneys to create justifications, which - as courts are often quick to note - they are not supposed to do under Chenery. ${ }^{45}$

Even when Chenery is not an issue, providing more thorough explanations would also reveal problems that may exist in the Board's conclusions. At times - again, not the majority, but not so rare that it could be considered an aberration - the Board seems to reach a conclusion without having fully thought through whether it was justified. Whether an attempt to compromise the positions of Board members or a lack of thoroughness, some Board decisions that appear simple on their face are wrong once a full analysis is performed. Other decisions may actually be correct, but seem wrong because of the Board's cursory or confusing analysis. Aside from fostering confusion, this superficial reasoning can cover up serious problems with the Board's conclusion and create a reputation for the Board as being merely result-oriented.

One example of the problems of inadequate explanations is the case Snyder's of Hanover. ${ }^{46}$ In Snyder's, the Board was faced with a last minute argument by the employer that it had the right to exclude union organizers from a public right-of-way because state property law gave adjoining land owners the power to exclude any use of public property unless that use is

\footnotetext{
as Member Acosta emphasized, there was little reason not to clarify the issue for the benefit of future parties or cases.

43 SEC v. Chenery, 318 U.S. 80, 94-95 (1943).

44 Id.

45 The Board's appellate attorneys typically refer to a rationale not explicitly contained in a Board decision as a "post hoc." Although a post hoc may be successful at times, they are particularly susceptible to a Chenery attack. See, e.g., Smithfield Packing Co. v. NLRB, 510 F.3d 507, 519 (4th Cir. 2007).

46 Snyder's of Hanover, 334 N.L.R.B. 183 (2001), enforcement denied in relevant part, 39 F. App'x 730 (3d Cir. 2002).
} 
specifically permitted by the relevant municipality. ${ }^{47}$ The Board correctly noted this state property rule, but did not apply it - instead, it brushed aside the employer's argument, stating that the employer did not provide evidence to support its right to exclude the union. ${ }^{48}$ However, the Third Circuit reversed, largely based on its own reading of the relevant state and local property law. The court was particularly dismissive of the Board's burden of proof conclusion, emphasizing that public records and judicial decisions were sufficient to address the employer's defense. ${ }^{49}$ Although the employer had a colorable argument, the Board's failure to substantively analyze the issue gave the employer a win it may not have deserved. There were weaknesses with the employer's argument that the Third Circuit did not address - for instance, two municipal officials had given the union permission to use the public land ${ }^{50}$ - largely because the Board itself did not address them. Had the Board engaged in more substantive analysis, the Third Circuit may have agreed with its conclusion or at least remanded to the Board to address some of the underlying issues in more detail.

There is no quick fix to this problem. The most important step would be to further emphasize the importance of fully reasoned decisions to the Board members' staffs. Having more Board staff attorneys with appellate experience would help as well. ${ }^{51}$ Board staff are no doubt aware that most Board decisions do not go to court. ${ }^{52}$ They also know well that the Board has the primary responsibility to interpret the NLRA and may take that role more seriously than is warranted given the Board's lack of power to enforce its decisions. The result, at times, is a failure to consider how a court may view the Board's decision or how an appellate attorney will have to defend it. The experience of having to defend a Board decision - particularly an inadequately or poorly reasoned one - will do much to illustrate the need to thoroughly explain the Board's reasoning in all of its decisions.

This problem could also be aided by increasing the use of oral arguments and invitations for amicus briefs in cases. The Board often does this

7 Id. at 183 n.4 (quoting City of Philadelphia v. Street, 63 Pa. D. \& C. 2 d 709 (1974)).

48 Id. at 184

39 F. App'x at 734.

Snyder's, 334 N.L.R.B. at 184.

51 The Board could provide such experience by hiring staff attorneys with appellate experience or using its "detail" program - basically a temporary transfer or visitorship - to give more Board-side attorneys appellate litigation experience.

52 See supra note 8.

53 See, e.g., Massey Energy Co., No. 9-CA-42057, 354 N.L.R.B. No. 83, 2009 WL 3149917, at*1 (Sept. 30, 2009) (severing unfair labor practices cases against parent and subsidiary companies and, in finding subsidiary liable, failing to identify whether it was relying only on conduct of the subsidiary or of both companies, as the ALJ had found). 
when it is considering a reversal of precedent, ${ }^{54}$ but other cases could also benefit from this approach. The Board's decisions in these cases are likely to benefit from more attention and input from interested parties. ${ }^{55}$ This in turn would improve the resulting decisions' chances before the courts, both because of the decisions' substantive quality and the perceived legitimacy with the process.

\section{Citing Appellate Court Cases in NLRB Decisions}

NLRB decisions, with some exceptions, have long been devoid of any mention of circuit court opinions. This is the result of the Board's view that it has the power to enforce the NLRA across the country; only Congress or the Supreme Court act as higher national authorities. ${ }^{56}$ Although technically true, this stance ignores the importance of appellate courts. The Supreme Court, which is increasingly hostile to the Board, ${ }^{57}$ takes very few labor cases. The appellate courts, therefore, serve as the court of last resort for virtually all NLRB cases. Accordingly, although the Board can maintain its stance as the ultimate arbitrator of NLRA policy, until it has the power to enforce its own decisions, it is a paper tiger.

Recognizing the important role of appellate courts in Board decisions has both practical and substantive benefits. Practically, acknowledging the courts' role will improve the Board's credibility with the courts and make the agency appear less combative. Substantively, regularly citing court decisions will improve the quality of Board decisions and highlight potential problems with court review while the Board still has a chance to address them.

Citing to court decisions more often would also require the Board to be more explicit about when and why it disagrees with a court. Although the Board is unlikely to change a court's mind in a specific instance, decreasing the perception that it is "hiding the ball" from courts could only improve the Board's credibility. ${ }^{58}$ Moreover, there may be instances where

54 See, e.g., Notice of Oral Argument and Invitation to File Briefs, New York New York Hotel, LLC, Case No.28-CA-14519 (N.L.R.B. Sept. 4, 2007), available at http://www.nlrb.gov/nlrb/about/foia/ NYNYHotelCasino/NoticeOfOralArgumentandInvitationtoFileBriefsdtd09042007.pdf. Note, however, that the Supreme Court has recently held that an agency need not take extra steps when changing its precedent; the agency must still identify the change and show that the new policy is permissible, but it need not show that the new policy is better than the old one. FCC v. Fox Tel. Stations, Inc., $129 \mathrm{~S}$. Ct. 1800, 1811 (2009).

55 Estreicher, supra note 1, at 14 n.43.

$56 C f$. Brudney, supra note 15, at 239 (noting, in discussion of nonaquiescence, Board's "insistence on its role as primary articulator of labor relations policy").

57 Id. at 242.

58 See Flynn, supra note 2. 
there is an apparent conflict with a previous court holding, but that a wellreasoned Board decision could instead distinguish. The NLRB's appellate attorneys attempt to do this frequently, but often run into the problem of courts calling them out for "post-hoc" arguments. ${ }^{59}$ By establishing a policy of citing relevant court decisions, the Board would do a better job of identifying potential conflicts or appearances of conflicts, and have the opportunity to give its appellate attorneys more ammunition to avoid a court reversal.

A practice of citing to court decisions would have other benefits as well. For instance, if it adopted this practice, the Board would likely cite to the law of the circuit with jurisdiction over the geographic area in which the principal facts occurred. ${ }^{60}$ By so doing, the Board would help signal to the court, where applicable, that the other side engaged in forum shopping. ${ }^{6}$ Citing relevant court decisions would also help the Board if it wanted to engage in more subtle or defensible forms of forum shopping, such as avoiding a circuit that is openly hostile to a specific Board rule at issue. ${ }^{62}$ Finally, if there are different circuit rules at play, the Board could explicitly conclude that the General Counsel met its burden under all of them, thereby making the decision easier to defend in whatever circuit the case ends up.

In short, citing to court decisions shows respect to the entities that are reviewing the Board. It also allows the Board to eliminate conflicts that are unnecessary or unwarranted. Moreover, when a conflict does occur, the practice would ensure that the Board addresses the problem directly. The result would likely be an increase in courts' approval of Board decisions.

\section{EMPHASIZING THE STANDARD OF REVIEW}

A further reform, which is related to improving the Board's decisions, would be to make more of a concerted emphasis in appellate briefs and during oral argument to stress the deferential standard of review. ${ }^{63}$ The

59 See Smithfield Packing Co. v. NLRB, 510 F.3d 507, 519 (4th Cir. 2007); supra text accompanying note 45 .

60 The Board would also be wise to cite to D.C. Circuit precedent, as that court has jurisdiction over all NLRB cases, no matter where the facts took place. 29 U.S.C. §160(e)-(f) (2006).

61 See infra Part III.

62 See 29 U.S.C. § 160(e)-(f); Laurel Baye Healthcare of Lake Lanier, Inc. v. NLRB, 564 F.3d 469 (D.C. Cir. 2009); Industrial Turn Around Corp. v. NLRB, 115 F.3d 248, 254 (4th Cir. 2007); see infra note 72 and text accompanying notes 72-75; $c f$. New Process Steel, L.P. v. NLRB, No. 08-1457, slip op. (U.S. June 17, 2010), rev'g 564 F.3d 840 (7th Cir. 2009).

63 That standard can differ depending on the situation. Generally, the Board is entitled to enforcement of decisions in which there is "substantial evidence" supporting its conclusions. 29 U.S.C. $\S$ 160(e); Universal Camera Corp. v. NLRB, 340 U.S. 474, 488 (1951). Courts also give increased deference to the Board's representational findings - such as bargaining unit determinations and election objections - as the agency is perceived to have a particularly strong expertise in that area vis á vis 
Board includes the appropriate standard of review in every appellate brief, and the courts are certainly aware of the need for deference to administrative agencies, but some appellate decisions would leave a reasonable reader to believe that courts review NLRB decisions de novo.

The review problem is often the result of the other issues discussed in this article. ${ }^{64}$ These reform efforts would hopefully minimize the number of times courts fail to give the Board the deference it is due, but a more effective approach would explicitly enhance the emphasis on the proper standard of review.

There are various ways of stressing the standard more. First, the standard of review section of NLRB briefs could be revamped to avoid the boring boilerplate language that is usually used and easily overlooked. ${ }^{65}$ By making those statements more forceful and targeted to a particular case, the Board could increase the likelihood that the court will take that standard seriously. ${ }^{66}$ That language should also use relevant appellate court citations. Second, more of an effort could be made to weave the standard of review throughout a brief's argument section. Third, Board attorneys could be more explicit and more consistent about raising the standard during oral argument. Attorneys do not need to be overbearing or awkward in their emphasis on the standard of review. Rather, it would take little effort to weave the standard into their descriptions of cases or, when acknowledging facts that go against the NLRB's findings, note that the Board's decision is still proper as long as there exists substantial evidence in support of its conclusions. These strategies would make the standard of review more promi-

courts. NLRB v. A. J. Tower Co., 329 U.S. 324, 330 (1946); Sitka Sound Seafoods, Inc. v. NLRB, 206 F.3d 1175, 1178 (D.C. Cir. 2000). Moreover, certain interpretations of the NLRA may be entitled to Chevron deference. See, e.g., Snell Island SNF, L.L.C. v. NLRB, 568 F.3d 410, 415 (2d Cir. 2009).

64 It may also be the result of certain judges not caring much about the standard of review. See Allentown Mack Sales \& Serv., Inc. v. NLRB, 522 U.S. 359, 363 (1998); Caterair Int'1 v. NLRB, 22 F.3d 1114, 1123 (D.C. Cir. 1994); see infra text accompanying notes 69-70.

65 To emphasize that I am writing on this issue with somewhat unclean hands, the following language from a brief I authored is a good example of a boilerplate statement of the standard of review: "The Board's findings are 'conclusive' if they are supported by substantial evidence on the record as a whole. A reviewing court, therefore, may not displace the Board's choice between conflicting views, "even if the court would justifiably have made a different choice had the matter been before it de novo." NLRB Appellate Brief, CSX Hotels, Inc. v. NLRB, 377 F.3d 294 (4th Cir. 2004) (Nos. 03-2274, 032432), 2004 WL 5230567.

66 While arguing cases for the NLRB, I was always thrilled to hear a judge bring up the standard of review during my opponent's opening argument. At that point, I knew my job was to make the quickest argument I could to avoid snatching defeat from the jaws of what looked to be almost certain victory. 
nent and hopefully result in judges respecting the Board's conclusions more often.

The risk of this strategy is that it could backfire. It is possible that an emphasis on the standard of review could be seen by some judges as a sign of weakness or desperation. In other words, a judge may see the Board's stress on the standard of review as a signal that the decision cannot stand on its own legs. Moreover, some judges may take offense at any statement that could be interpreted as suggesting that the Board's conclusions are entitled to more weight than judges'.

Although these risks are real, they could be lessened by a general, consistent emphasis on the standard of review. By making clear that it views agency deference as an important, and often ignored, part of its administrative powers, the Board could limit some of this backlash. It would no doubt still occur on occasion, but the hope is that the benefits outweigh the costs. The Board would also need to be careful not to blindly cite the need for deference without giving courts reason to think that deference is deserved. By explaining its decisions better and showing why its expertise is relevant to a given case, ${ }^{68}$ the Board's stress on the importance of a deferential standard of review would be more likely to receive a positive reception.

Whether the benefits would materialize is not certain, however. Especially when focusing on close or controversial cases, it is unclear whether a judge's increased attention to agency deference would matter. A judge may simply make the decision she feels is correct, no matter the standard. ${ }^{6}$ Although this is no doubt true in some instances, it is also likely that other judges may be less willing to reverse the Board when they have the need for deference firmly in mind. ${ }^{70}$ It is impossible to quantify, but it appears that a long-term emphasis on the standard of review - particularly where the Board has also made reforms that help it to earn more respect - would give the agency more judicial deference than it enjoys today.

67 The Board does this in many cases, but there appear to be many opportunities to make such an emphasis. In short, the Board should consider emphasizing the standard of review as a matter of policy rather than on an ad hoc basis.

68 See supra Part I.B; Brudney, supra note 15, at 240.

69 See, e.g., Caterair Int'l v. NLRB, 22 F.3d 1114, 1123 (D.C. Cir. 1994) (holding that the Board "must affirmatively demonstrate [to the court] its consideration of the competing values at stake" before making an affirmative bargaining order despite acknowledging the particularly strong deference owed to the Board's choice of remedies).

70 Allentown Mack Sales \& Serv., Inc. v. NLRB, 522 U.S. 359, 364 (1998) ("While the Board's adoption of a unitary standard for polling, RM elections, and withdrawals of recognition is in some respects a puzzling policy, we do not find it so irrational as to be 'arbitrary [or] capricious' within the meaning of the Administrative Procedure Act."). 


\section{FORUM SHOPPING}

Another means by which the NLRB could increase its chances of appellate success is to avoid those courts that are most hostile to the Board. This "forum shopping" could take many forms; however, any attempt to target or to avoid a specific court of appeals would require a change of the Board's current practice of avoiding even the hint of forum shopping. There are good reasons for the Board's current policy, so a wholesale change to a more mercenary litigation strategy would not be wise. Yet, a more limited practice of avoiding circuit law that directly conflicts with the NLRB's policies may be warranted.

Currently, the NLRB's Appellate Court Branch typically follows the practice of waiting thirty days after the Board has issued a decision before seeking enforcement in a court of appeals. This procedure gives the losing party the first opportunity to file an appeal and ensures that the agency does not appear to be shopping for a favorable circuit. Similarly, when the NLRB does petition a court for enforcement of its orders, it files with the circuit having geographic jurisdiction over the area in which most of the central facts of a case occurred. The sum of these practices is a very strong anti-forum shopping policy.

This policy derives from the NLRB's admirable desire to appear impartial and to avoid any appearance of gaming the courts. That concern is also reflected in the NLRB's brief writing and oral arguments, as appellate attorneys are instructed to act in a way that maintains the Board's credibility as a repeat player before the courts and as a representative of the federal government. These goals are well-justified and caution strongly against any change that may raise even a suggestion that the NLRB is basing its decisions where to file on a view that the judges of one court are more sympathetic to the Board than those of another. The Board's antiforum shopping policy also avoids angering judges who would be offended by the appearance of an agency trying to seek more sympathetic courts. But not all forum-shopping policies raise these concerns.

At times, the NLRB faces circuits that have established rules that directly contradict those of the NLRB and other circuits. ${ }^{71}$ If the NLRB continues to apply rules that certain circuits have rejected - using its "nonacquiescence policy",72 - the Board's anti-forum shopping policy causes serious problems. By giving the losing party thirty days to file, the NLRB

\footnotetext{
71 See, e.g., Industrial TurnAround Corp. v. NLRB, 115 F.3d 248, 254 (4th Cir. 2007).

72 See Brudney, supra note 15, at 237-40; Rebecca Hanner White, Time for a New Approach: Why the Judiciary Should Disregard the "Law of the Circuit" When Confronting Nonacquiescence by the National Labor Relations Board, 69 N.C. L. REV. 639, 639-40 (1991); see generally Samuel Estreicher \& Richard L. Revesz, Nonacquiescence by Federal Administrative Agencies, 98 YALE L.J. 679 (1989).
} 
is literally giving away these cases; the party will almost certainly file with the circuit that has stated that it will not enforce the exact type of Board decision at issue. ${ }^{73}$ It does not undermine the NLRB's neutrality or credibility to actively avoid a court that will, with certainty, reverse the Board. To do otherwise wastes the NLRB's time and, more importantly, allows employees to suffer what the agency has already deemed a violation of the NLRA without remedy.

Indeed, the Board has recently been faced with the most serious type of this problem. The D.C. Circuit - which has jurisdiction over any NLRB decision, no matter where the facts occurred ${ }^{74}-$ held all NLRB cases in abeyance until the Supreme Court addressed whether the Board could issue decisions with only two members. ${ }^{75}$ This problem was solved with the recent appointments of new Board members, but it was a severe issue for the twenty-six months during which the Board had only two members - and the problem could soon arise again. ${ }^{76}$ No matter the reasons to avoid forum shopping in normal circumstances, there was no sense in allowing losing parties to file petitions for review in the D.C. Circuit, knowing that nothing would happen until more Board members were appointed or the Supreme Court resolved the issue. As soon as the D.C. Circuit held that the twomember decisions were invalid - and certainly as soon as the court announced it was holding NLRB cases in abeyance - the NLRB should have established a policy of filing quickly for enforcement in circuits that were actually considering Board cases.

Beyond the cases with the most obvious conflicts, the NLRB should also consider avoiding circuits that are openly hostile to its law on certain issues. For instance, the Sixth Circuit, before being reversed by the

73 See Industrial TurnAround, 115 F.3d at 254.

7429 U.S.C. $§ 160(\mathrm{e})-(\mathrm{f})(2006)$.

75 Laurel Baye Healthcare of Lake Lanier, Inc., v. NLRB, 564 F.3d 469 (D.C. Cir. 2009) (holding that NLRB does not have authority to issue two-member decisions); $c f$. New Process Steel, L.P. v. NLRB, No. 08-1457, slip op. (U.S. June 17, 2010), rev'g 564 F.3d 840 (7th Cir. 2009) (holding that the NLRB lacked authority to issue decisions under delegated two-member Board).

76 See Stephen Greenhouse, Deadlock is Ending on Labor Board, N.Y. TimES, Apr. 1, 2010, at B1.

77 The First, Second, Fourth, Seventh, and Tenth Circuits all agreed that two-member NLRB decision were valid; thus, the Board could have filed cases in at least those circuits and possibly the remaining circuits that had not addressed the issue yet. See Narricot Indus., LP v. NLRB, 587 F.3d 654, 659 (4th Cir. 2009); Snell Island SNF L.L.C. v. NLRB, 568 F.3d 410, 423-24 (2d Cir. 2009); New Process Steel, L.P., 564 F.3d 840, 845-46 (2009), rev'd, No. 08-1457, slip op. (U.S. June 17, 2010); Ne. Land Servs., Ltd. v. NLRB, 560 F.3d 36, 41 (1st Cir. 2009). Eventually, the NLRB seemed to avoid the D.C. Circuit, as it began not to wait the normal 30 days before filing in the circuit in which the majority of facts took place. See Appellate Court Branch Briefs and Motions (showing lack of D.C. Circuit appellate cases following Laurel Baye), http://www.nlrb.gov/research/appellate_court_briefs_and_ motions.aspx (last visited Aug. 26, 2010). 
Supreme Court, used to hold that the NLRB's General Counsel bore the burden of proving that a worker was not an excluded supervisor under the NLRA. ${ }^{78}$ This contrasted with the approach of the Board and other circuits, which placed the burden on the party arguing that a worker was a supervisor. ${ }^{79}$ Although the Board would not automatically lose a supervisor case before the Sixth Circuit, the court's rule was dissimilar enough to the Board's interpretation of the NLRA that avoiding the Sixth Circuit in supervisor cases would have been warranted.

This type of case, although not technically raising the Board's nonaquiescence policy, may be considered "nonacquiescence light." 80 Such cases involve issues in which courts, although not fully contradicting Board law, are hostile to the Board's rulings. Avoiding those courts in cases raising such issues has more justification than forum shopping that merely tries to increase the Board's odds of winning. Instead, these cases involve situations in which the Board is very likely to lose. It would not significantly affect the Board's reputation to file with other courts under such circumstances. $^{81}$

\section{RULEMAKING}

The NLRB is unique among administrative agencies in its use of adjudication rather than formal rulemaking. Much has been written about the NLRB's failure to use rulemaking and its effect on NLRA enforcement, and this article will not repeat that literature. ${ }^{82}$ However, it is worth examining how an increased use of rulemaking might influence court review of NLRB cases.

Despite its authority to issue rules, the NLRB has steadfastly refused to do so in all but the narrowest of circumstances. ${ }^{83}$ One theory for this practice is that the reliance on adjudication rather than rulemaking improves 711 (2001).

78 Ky. River Cmty. Care, Inc. v. NLRB, 193 F.3d 444, 453 (6th Cir. 1999), rev'd, 532 U.S. 706,

79 NLRB v. Ky. River Cmty. Care, Inc., 532 U.S. 706, 711 (2001).

80 Another example involves the Board's disagreement with courts, particularly the D.C. Circuit, regarding when affirmative bargaining orders are appropriate. See Brudney, Victory, supra note 2, at 1012 n.237 (citing cases).

81 The Board may well irritate these courts, although they have already shown hostility to the NLRB's decisions, so any additional irritation is unlikely to make a significant impact on the Board's success rate.

82 See, e.g., William B. Gould IV, New Labor Law Variations of an Old Theme: Is the Employee Free Choice Act the Answer?, 70 LA. L. REV. 1, $42-44$ (2009) (citing past articles); Mark H. Grunewald, The NLRB's First Rulemaking: An Exercise in Pragmatism, 41 DuKE L.J. 274 (1991); Samuel Estreicher, Policy Oscillation at the Labor Board: A Plea for Rulemaking, 37 ADMIN. L. REV. 163 (1985).

83 Am. Hosp. Assoc. v. NLRB, 499 U.S. 606, 608, 609, 620 (1991) (approving NLRB health-care bargaining-unit rule as valid exercise of authority under Section 6 of the NLRA, 29 U.S.C. $\S 156$ (2006)). 
the Board's success before the courts of appeals, as it "hides the ball" - that is, the Board is able to hide controversial policy judgments under the guise of fact finding. ${ }^{84}$ As the NLRB learned when it tried to implement a rule establishing a presumption that single-facility bargaining units were appropriate, Congress also tends to notice proposed rules more than adjudicatory holdings. ${ }^{85}$ Thus, the NLRB has reasonably been wary of relying on rules to issue policy.

Rulemaking, especially for an agency that is relatively new to the practice, would also consume a significant amount of resources. ${ }^{86}$ Funding is almost always a serious issue for the NLRB, so even if it wanted to engage in more rulemaking, its power to do so would be constrained.

Despite these reasons for avoiding rules in certain instances, there are potential benefits from at least limited rulemaking. For instance, establishing clear rules that apply in specific, narrow circumstances would lend an air of legitimacy that adjudication often lacks. ${ }^{87}$ In particular, where the Board decides to reverse its previous law, doing so through rulemaking where appropriate - could increase courts' willingness to defer to the Board's change. ${ }^{88}$ Much of the advantage in these instances derives from a more thorough explanation of the Board's reasons for a policy and a more explicit recognition of competing views on an issue. ${ }^{89}$ This explanatory

84 See Flynn, supra note 2, at 405-13; see also Gould, supra note 82, at 29 (citing decision to grant backpay to undocumented workers in Hoffman Plastics). Indeed, adjudications that go against unions in representation cases are, unlike rulemaking, totally immune from court review. Catherine L. Fisk \& Deborah C. Malamud, The NLRB in Administrative Law Exile: Problems with its Structure and Function and Suggestions for Reform, 58 DUKE L.J. 2013, 2068 (2009) (noting that employees and union cannot challenge the Board's representation decisions). The Board may try to hide policy decisions from Congress in a similar manner. Estreicher, Improving, supra note 1, at 12.

85 After the NLRB proposed a rule to establish a presumption that single-location bargaining units were presumptively appropriate, Congress attached several riders to the NLRB's budget prohibiting the spending of funds to promulgate the rule. See Unified Agenda, National Labor Relations Board, 61 Fed. Reg. 63,528, 63,528-29 (Nov. 29, 1996). Eventually, the NLRB withdrew its notice of proposed rulemaking. See Unified Agenda, National Labor Relations Board, 63 Fed. Reg. 23,036, 23,036-37 (Apr. 27, 1998).

86 This is especially true given that the NLRB is banned from hiring economic analysts. 29 U.S.C. § 154(a) (2006) ("Nothing in this Act shall be construed to authorize the Board to appoint individuals ... for economic analysis.").

87 Gould, supra note 82, at 43.

88 Estreicher, supra note 1, at 14. Some situations are so context-dependent that adjudication is more appropriate than rulemaking.

89 Brudney, supra note 15, at 235-36 (noting that rulemaking "encourages the collection and analysis of information at a more complete and sophisticated level"). The NLRB often does provide opposing parties' views in cases, particularly significant ones. However, this is still less useful than rulemaking because it only includes the views of parties (and amici in limited circumstances), rather than the broader set of views usually associated with rulemaking. Also, courts are more used to seeing opposing views as part of the rulemaking process; the courts are less familiar with the Board's custom, which is likely to reduce their respect for the NLRB's process. 
power would likely provide Board rules with increased deference from courts. Rulemaking's increased predictability may also reduce the hostility that some courts exhibit towards the Board's adjudications.

Examples of issues that could lend themselves to rulemaking, particularly in the Board's initial attempts, include requiring postings that notify employees of certain labor rights, ${ }^{90}$ promulgating remedial rules, ${ }^{91}$ and establishing basic guidelines for elections and other representational issues. ${ }^{92}$ With these rules in place, the NLRB could then focus on applying its policies to the facts of cases before it - a practice that is particularly suited for adjudication.

Despite these potential advantages, courts or Congress could still reject the NLRB's rules. However, given courts' willingness to reverse NLRB decisions, this risk does not seem worse than the status quo. ${ }^{93}$ Moreover, by engaging in formal rulemaking, courts would have to apply the Supreme Court's Chevron rule which, although not foolproof, could provide more deference than the Board usually enjoys. ${ }^{94}$ Thus, the Board should consider rulemaking in certain instances as one option for protecting its decisions from court reversal. It is a strategy that comes with costs, but if used wisely, it may provide substantial benefits.

90 These notices could include narrow ones, such as the recently implemented one notifying employees of their right to seek decertification of a union that an employer recently voluntarily recognized, see Dana Corp., 351 N.L.R.B. 434, 443 (2007), or a more general posting notifying employees of their general NLRA rights, see Jeffrey M, Hirsch, Communication Breakdown: Reviving the Role of Discourse in the Regulation of Collective Action, UC DAVIS L. REV. (forthcoming 2011), manuscript at 62-63, available at: http://papers.ssrn.com/abstract_id=1553031). In 1992, the Board proposed a rule that would notify employees of their "Beck" rights not to pay all union dues in some circumstances. See 57 Fed. Reg. 43, 635 (Sept. 22, 1992); see also Commc'ns Workers v. Beck, 487 U.S. 735 (1988). However, the Board later rescinded the notice of proposed rulemaking. See 61 Fed. Reg. 11, 167 (Mar. 19, 1996).

91 See, e.g., Anheuser-Busch, Inc., 351 N.L.R.B. 644, 650 (2007) (prohibiting make-whole remedy for employees terminated for misconduct discovered by unlawful employer surveillance).

92 See Jeffrey M. Hirsch, The Silicon Bullet: Will the Internet Kill the NLRA, 76 GEO. WASH. L. REV. 262, 302 (2008) (arguing for expansion of Excelsior lists for employees' e-mail addresses); Estreicher, Oscillation, supra note 82 , at 172-74 (arguing for rules to simplify bargaining unit determinations and when to issue bargaining orders). See generally NLRB v. Wyman-Gordan Co., 394 U.S. 759, 76364, 772 (1969) (affirming Exclesior and holding that Board can issue rules through formal rulemaking or adjudication).

93 See Flynn, supra note 2, at 419-20, 433-34 (noting that Board's practice of hiding rules through adjudication can produce hostile reaction from courts, although also noting the risk that rulemaking is an easy target for courts).

94 But see Flynn, supra note 2, at 438 (arguing that Chevron provides similar deference to the traditional standard of review - "rational and consistent" with the NLRA - for NLRB policymaking); see also Michael Harper, Judicial Control of the National Labor Relations Board's Lawmaking in the Age of Chevron and Brand X, 89 B.U. L. REV. 189, 191 (2009) (arguing that courts should use a heightened "arbitrary and capricious" review in some circumstances, particularly where the NLRB's rules change). 


\section{REDUCING DELAY}

Delays in the NLRB's issuance of decisions is a further concern for the Board's ability to successfully defend its cases in court. In addition to diminishing its credibility, ${ }^{95}$ in certain cases courts expressly cite delay as a reason to refuse to enforce a Board order. ${ }^{96}$

The time it takes the NLRB to investigate and adjudicate an unfair labor practice charge is considerable. ${ }^{97}$ In Fiscal Year 2009, it took on average 483 days from the filing of a charge to the issuance of an NLRB decision. ${ }^{98}$ However, the delay can be much longer; for example, the cases still awaiting decisions at the end of Fiscal Year 2009 had been pending on average for 963 days since the issuance of the charge. ${ }^{99}$

This delay can directly impact the Board's success in the courts of appeals. Indeed, the courts frequently call out the Board for its delay, oftentimes resulting in reversals. ${ }^{100}$ This is particularly true for affirmative bargaining orders, in which courts will often rely on the passage of time to refuse to enforce the Board's remedy. ${ }^{101}$ These bargaining cases show the double-edged sword of delay; not only does the time it takes to litigate a case undermine a union's ability to maintain support from employees, but even if a union can keep the support, the bargaining remedy may ultimately be overturned. ${ }^{102}$

The NLRB has been working at reducing delay over the last several years, with some success. ${ }^{103}$ Yet, more could be done. One recurring issue has been the amount of time during which the NLRB has lacked its full

95 See generally Samuel Estreicher \& Matthew T. Bodie, Administrative Delay at the NLRB: Some Modest Proposals, 23 J. LAB. RES. 87 (2002); John C. Truesdale, Battling Case Backlogs at the NLRB: The Continuing Problem of Delays in Decision Making and the Clinton Board's Response, 16 LAB. LAW. 1 (2000).

96 See, e.g., NLRB v. Thill, 980 F.2d 1137, 1142 (7th Cir. 1992).

97 Delay is a serious issue with representation cases, but because representation issues only reach courts of appeals via unfair labor practice charges, the focus here will be on those cases.

9874 NLRB ANNUAL REPORT: FisCAL YEAR 2009, at 152 (2010) (median days).

99 NLRB ANNUAL REPORT, supra note 98.

100 See Wilma B. Liebman \& Peter J. Hurtgen, The Clinton Board(s) - A Partial Look from Within, 16 LAB. LAW. 43, 45-46 (2000) (citing decisions noting the Board's "snail-like pace" and "cavalier disdain for the hardships it is causing," and that its delay is a "dilatory virus"); see also Thill, 980 F.2d at 1142, 1143 (rejecting bargaining order because of nine-year delay, and calling Board the "Rip Van Winkle" of administrative agencies).

101 See Thill, 980 F.2d at 1142.

102 See supra note 9.

103 The delay from the filing of a charge to issuance of a decision was a median 483 days in fiscal year 2009 and 559 days in 2008. 74 NLRB ANNUAL REPORT: FISCAL YEAR 2009, at 152 (2009); 73 NLRB ANNUAL REPORT: FISCAL YEAR 2008, at (2009). 
complement of five members. ${ }^{104}$ Even when at full strength, however, there still remains a need to further reduce the delay in issuing decisions. Options to address this need include setting internal limits on the amount of time a Board member is permitted to issue an assigned decision and giving the Chairperson the power to reassign cases away from members who do not meet those deadlines. ${ }^{105}$ If funding were less of an issue, increased staffing would help as well.

The problems of delay are by no means limited to the Board's appellate success. But when considering its priorities, both budgetary and policy-wise, the Board should take into account the negative impact that delay has on its ability to defend its cases before the courts of appeals. If it wants its orders to be enforced - especially its bargaining orders - it should intensify its attempts to reduce the amount of time that it takes to handle cases.

\section{10(E) MOTIONS}

In addition to the delay involved while the Board is considering a case, the time an appellate court takes to hear a case can also be a significant issue. The NLRA provides the Board with an option to mitigate the effects of such delay by seeking injunctive relief under Section $10(\mathrm{e}){ }^{106}$ This option could not only provide faster relief for the victims of unfair labor practices, but also improve the Board's chance of success once a full appellate decision is issued.

A Section 10(e) motion seeks a preliminary injunction from a court; for instance, an injunction requiring an employer to continue to bargain with a union while the court is considering a Section 8(a)(5) unfair labor

104 See Laurel Baye Healthcare of Lake Lanier, Inc., v. NLRB, 564 F.3d 469 (D.C. Cir. 2009) (holding that NLRB does not have authority to issue two-member decisions); $c f$. New Process Steel, L.P. v. NLRB, No. 08-1457, slip op. (U.S. June 17, 2010), rev'g 564 F.3d 840 (7th Cir. 2009) (holding that the NLRB lacked authority to issue decisions under delegated two-member Board).

105 Estreicher, Improving, supra note 1, at 12. The view that the Board has become increasingly partisan may also cause delay and create less respect from the courts; however, there is not much that the Board itself can realistically do about this problem, given that members may be chosen specifically because they are highly partisan. See James J. Brudney, Recrafting a Trojan Horse: Thoughts on Workplace Governance in Light of Recent British Labor Law Developments, 28 COMP. LAB. L. \& POL'Y J. 193, 205 (2007); Wilma B. Liebman, Decline and Disenchantment: Reflections on the Aging of the National Labor Relations Board, 28 BERKELEY J. EMP. \& LAB. L. 569, 579 n.71 (2007) (citing increased politicization of NLRB, which results in more vacancies, more turnover, and more delay); Truesdale, supra note 95.

10629 U.S.C. § 160(e) (2006); see also John G. Adam, Achieving Compliance with NLRB-Ordered Remedies, 75 U. DeT. MERCY L. REV. 323, 326-27 (1998); Charles J. Morris, Renaissance at the NLRB - Opportunity and Prospect for Non-Legislative Procedural Reform at the Labor Board, 23 STETSON L. REV. 101, 123-27 (1993). 
practice finding. ${ }^{107}$ Along with Section 10(j) motions, ${ }^{108}$ the district court injunction equivalent, Section 10(e) injunctive relief is a means for the Board to avoid some of the problems associated with its lack of authority to enforce its orders. ${ }^{109}$ Moreover, seeking Section $10(\mathrm{e})$ injunctive relief may not only aid the enforcement of the NLRA while a case is pending, but could also enhance a case's ultimate chance of success before a court by providing a signal that the Board's reasoning is strong and the issues involved are significant. Therefore, it is curious that although the NLRA explicitly authorizes such motions, the NLRB is reticent to seek injunctive relief from appellate courts, even less so than the underutilized Section 10(j) relief. ${ }^{110}$ Indeed, Section $10(\mathrm{e})$ motions have been virtually nonexistent over the last few years. ${ }^{11}$

One reality that has played into this reticence is the fact that appellate courts are resistant to granting Section 10(e) motions, despite the relatively low threshold for justifying such relief. ${ }^{112}$ The Board has attempted at times to file more Section $10(\mathrm{e})$ motions, but often without success. ${ }^{113}$ For example, in several cases before the D.C. Circuit, the Board argued that Section 10 (e) orders were justified because of the Board's high win rate in the type of cases involved and the significant harm of delay. ${ }^{114}$ The court, however, was unmoved. $^{115}$ The reason for this resistance is not entirely clear, but probably results in part from the typical duties of the courts of appeals. ${ }^{16}$

10729 U.S.C. $\S 158(\mathrm{a})(5)$.

108 Id. $\S 160(\mathrm{j})$; see also William B. Gould IV, LABOred Relations: LAW, Politics, and the NLRB 65-67, 178-82, 300-02 (2000) (discussing importance of Section 10(j) relief).

109 See Morris, supra note 106, at 115-16.

110 See Catherine L. Fisk \& Deborah C. Malamud, The NLRB in Administrative Law Exile: Problems with its Structure and Function and Suggestions for Reform, 58 DUKE L.J. 2013, 2028-30 (2009) (discussing use of Section 10(j) motions, showing significant decline from1970s to 2000s).

11174 NLRB ANNUAL REPORT: FISCAL YEAR 2009, 149 (2010) (zero Section 10(e) motions; twenty-seven Section 10(j) motions); 73 NLRB ANNUAL REPORT: FISCAL YEAR 2008, 135 (2009) (zero Section 10(e) motions; twenty-one Section 10(j) motions); 72 NLRB ANNUAL REPORT: FISCAL YEAR 2007, 181 (2008) (three Section 10(e) motions; twenty-one Section 10(j) motions).

112 The requirements for Section 10(e) or Section 10(j) relief are usually less than a typical preliminary injunction, which requires a showing of irreparable harm; the Board instead need only show that there is reasonable cause that the NLRA was violated and that temporary relief will serve the remedial purposes of the Act. Ex-Cell-O Corp. v. NLRB, 449 F.2d 1046, 1051 (D.C. Cir. 1971).

113 See 64 NLRB AnNual RePort: Fiscal Year 1999, at 159 (2000) (noting two Section 10(e) filings, neither of which were granted). However, the most recent year in which the Board sought Section 10(e) relief, they won all three times. 72 NLRB ANNUAL REPORT: FISCAL YEAR 2007, at 181 (2008). If the Board were more aggressive about seeking such relief, that win rate would likely be lower.

114 See, e.g., All Seasons Climate Control, Inc. v. NLRB, 236 F. App'x 636 (D.C. Cir. 2007); Interstate Waste Servs. of N.J., Inc. v. NLRB, 236 F. App'x 636 (D.C. Cir. 2007).

115 All Seasons, 236 F. App'x 636; Interstate Waste Servs., 236 F. App’x 637.

116 Political resistance to a more aggressive NLRB enforcement strategy is also a possible factor. See James J. Brudney, Reflections of Group Action and the Law of the Workplace, 74 TEX. L. REV. 1563, 
These courts are appellate in nature; they primarily review lower-court and agency decisions by reading opposing briefs, holding oral arguments, and issuing written decisions. Motions for preliminary appellate injunction are not typical and, as a result, appellate courts are less likely to be open to requests for such relief. That said, injunctive motions are not totally alien to these courts and a concerted effort by the NLRB to seek more Section 10 (e) relief could help courts become more comfortable with the process.

Yet, if the NLRB does file more Section 10(e) motions, it is not clear what effect those motions might have on the Board's ultimate success in the cases involved or cases in which they do not seek motions. It is possible that a well-reasoned strategy by the Board could help to flag cases that are strong on the facts and involve orders that are particularly susceptible to the harms of delay - thereby leading courts to side with the Board more often in the ultimate disposition. ${ }^{117}$ On the other hand, there is a risk that if the Board begins to file a substantial number of Section 10(e) motions, cases in which the Board did not file for such relief motion will be viewed by courts as weaker. Despite this risk, the Board should seriously consider seeking Section 10(e) relief more often.

At a minimum, the Board should routinely file Section 10(e) motions in cases in which it received Section 10(j) relief from a district court and there are no new circumstances weighing against such relief. These cases typically involve bargaining orders or other types of relief that can be undermined by the passage of time, and success before a district court provides the Board with more than enough justification to seek identical relief before a court of appeals. ${ }^{118}$ The Board could also seek injunctive relief in cases involving multiple or serious unfair labor practices and a significant passage of time. Filing Section 10(e) motions in such cases would be a means of emphasizing the harm that the alleged victims continue to face and hopefully make the court at least somewhat sympathetic to the Board's

1593 n.124 (1996) (discussing political backlash to NLRB's increased focus on Section 10(j) motions). Delay before the case was brought to the appellate court can also be an issue. Ex-Cell-O Corp., 449 F.2d at 1053 (citing union and NLRB delay).

117 Cases involving bargaining orders are among those in which delay is particularly harmful. See supra note 9. Also, if Section 10(e) motions are limited to only the strongest of cases - those in which the Board would presumably win anyone - there is little advantage from a final win-loss view to filing for Section 10(e) relief.

118 See Charles J. Morris, Deterring 8(a)(3) Discharges with 10(J) Injunctions: Professor Morris' Comments on the Katz et al. Commentary, 4 EMP. RTS. \& EMP. POL'Y J. 75, 76 (2000) (arguing that the Board should seek Section 10(j) relief in all discriminatory discharge cases); Samuel Estreicher, Labor Law Reform in a World of Competitive Product Markets, 69 CHI.-KENT L. REV. 3 , 36 (1993) (arguing for amendment to Section $10(\mathrm{j})$ to make clear that injunction is available to reinstate discharged employees). 
desire to have its order enforced. ${ }^{119}$ These motions are unlikely to have a dramatic effect, but for an agency whose value often seems to be questioned, they represent one of several strategies that could enhance the Board's standing among the courts of appeals.

\section{CONCLUSION}

The NLRB's success in the courts of appeals is by no means the agency's most pressing issue. It is, however, one that often appears to be overlooked. This is unfortunate, as a consistent and wide-reaching effort to improve its win rate in court would have many beneficial side effects. Keeping appellate review in mind while writing NLRB decisions, in particular, would add much value to the Board's adjudicatory efforts. Other strategies - such as emphasizing deference, avoiding overtly hostile courts, using more rulemaking, reducing delay, and seeking more injunctive relief - would also enhance the Board's standing before the courts and possibly with other audiences as well.

Appellate review is only one of many steps in NLRB litigation, but in many cases it is the final one. Without court approval in these cases, all that has occurred before may be for naught. Thus, to preserve the Board's efforts to enforce the NLRA and to increase its credibility as an agency, it is vital that the Board focus on what is needed to achieve success in the courts of appeals.

119 Despite the appellate courts criticism of NLRB delay, the courts are not immune from this problem. Seeking 10(e) relief, while possibly being seen as overly critical, could also push courts to act faster in certain cases. 